\title{
Green Perylene Bisimide Dyes: Synthesis, Photophysical and Electrochemical Properties
}

\author{
Che-Wei Chang, Hsing-Yang Tsai and Kew-Yu Chen *
}

Department of Chemical Engineering, Feng Chia University, Taichung 40724, Taiwan; E-Mails: m0111617@fcu.edu.tw (C.-W.C.); 00156676@fcu.edu.tw (H.-Y.T.)

* Author to whom correspondence should be addressed; E-Mail: kyuchen@fcu.edu.tw; Tel.: +886-424-517-250 (ext. 3683); Fax: +886-424-510-890.

Received: 14 June 2014; in revised form: 18 July 2014 / Accepted: 23 July 2014 /

Published: 25 July 2014

\begin{abstract}
Three asymmetric amino-substituted perylene bisimide dyes with different $n$-alkyl chain lengths ( $n=6,12$, or 18$), 1$-( $N, N$-dialkylamino)perylene bisimides (1a-1c), were synthesized under mild condition in high yields and were characterized by ${ }^{1} \mathrm{H} N M R$, ${ }^{13} \mathrm{C}$ NMR (nuclear magnetic resonance), HRMS (High Resolution Mass Spectrometer), $\mathrm{UV}-\mathrm{Vis}$ and fluorescence spectra, as well as cyclic voltammetry (CV). These molecules show intense green color in both solution and solid state and are highly soluble in dichloromethane and even in nonpolar solvents, such as hexane. The shapes of the absorption spectra of 1a-1c in solid state and in solution were found to be virtually the same, indicating that the long alkyl chains could efficiently prevent aggregation. They exhibit a unique charge transfer emission in the near-infrared region, of which the peak wavelengths show strong solvatochromism. The dipole moments of the compounds have been estimated using the Lippert-Mataga equation, and upon excitation, they show larger dipole moment changes than that of 1-aminoperylene bisimide (2). Furthermore, all of the compounds exhibit two quasi-reversible one-electron oxidations and two quasi-reversible one-electron reductions in dichloromethane at modest potentials. Complementary density functional theory (DFT) calculations performed on these dyes are reported in order to rationalize their molecular structures and electronic properties.
\end{abstract}

Keywords: green dyes; 1-( $N, N$-dialkylamino)perylene bisimides; intramolecular charge transfer; solvatochromism; Lippert-Mataga equation; density functional theory calculations 


\section{Introduction}

Perylene bisimides (PBIs) and their related derivatives have continuously received significant attention due to their potential applications in molecular optoelectronic devices, such as organic field-effect transistors (OFETs) [1-6], photovoltaic cells [7-16], light-emitting diodes [17-21], light-harvesting arrays [22,23], photochromic materials [24,25], molecular wires [26,27] and LCD color filters [28,29]. In addition, PBIs have been used as building blocks to construct supramolecular or artificial photosynthetic systems [30-33]. These organic dyes are advantageous, due to their high molar absorptivities, reversible redox properties and optical stabilities, ease of synthetic modification and excellent thermal stability [34-55]. The electronic characteristics of PBIs can also be fine-tuned by the substitution of the conjugated aromatic core. Based on these principles, many perylene bisimide derivatives with either electron-withdrawing or electron-donating groups have been reported in the literature, including: (1) cyano-substituted PBIs [56,57]; (2) nitro-substituted PBIs [58-60]; (3) perfluoroalkyl-substituted PBIs [61,62]; (4) aryl-substituted PBIs [63,64]; (5) ferrocenyl-substituted PBIs [65,66]; (6) boryl-substituted PBIs [67]; (7) alkyl-substituted PBIs [68]; (8) hydroxy-substituted PBIs [69,70]; (9) alkoxy-substituted PBIs [71-75]; (10) amino-substituted PBIs [76,77]; (11) alkylamino-substituted PBIs [78-80]; (12) pyrrolidinyl-substituted PBIs [81-83]; (13) piperidinyl-substituted PBIs [84-86]; etc.

To date, a useful strategy for introducing substituents onto the PBIs core is bromination of perylene dianhydride. Subsequently, nucleophilic substitutions and metal-catalyzed cross-coupling reactions can then be executed. However, these reactions are usually accompanied by extensive debromination [78] and stringent reaction conditions, such as high temperatures and absence of water and oxygen. In an effort to expand the scope of PBI-based chromophores available for designing systems for colorful dyes and charge transport, we synthesized a series of purple dyes based on 1-aminoperylene bisimides [76]. We now report on the introduction of different long alkyl chains of 1-aminoperylene bisimide (2) affording chromophores (1a-1c) that are intense green in color and that readily undergo two quasi-reversible one-electron oxidations and two quasi-reversible one-electron reductions.

\section{Experimental Section}

\subsection{General}

The starting materials, such as perylene-3,4,9,10-tetracarboxyldianhydride, cyclohexylamine, acetic acid, $N$-methyl-2-pyrrolidinone (NMP), cerium (IV) ammonium nitrate (CAN), tin (II) chloride dihydrate $\left(\mathrm{SnCl}_{2} \cdot 2 \mathrm{H}_{2} \mathrm{O}\right)$, tetrahydrofuran (THF), sodium hydride $(\mathrm{NaH})$, 1-iodohexane $\left(\mathrm{C}_{6} \mathrm{H}_{13} \mathrm{I}\right)$, 1-iodododecane $\left(\mathrm{C}_{12} \mathrm{H}_{25} \mathrm{I}\right)$ and 1-iodooctadecane $\left(\mathrm{C}_{18} \mathrm{H}_{37} \mathrm{I}\right)$ were purchased from Merck (Whitehouse Station, NJ, USA), ACROS (Pittsburgh, PA, USA) and Sigma-Aldrich (St. Louis, MO, USA). Solvents were distilled freshly according to standard procedures. Column chromatography was performed using silica gel Merck Kieselgel si 60 (40-63 mesh). ${ }^{1} \mathrm{H}$ NMR spectra were recorded in $\mathrm{CDCl}_{3}$ on a Bruker $400 \mathrm{MHz}$ NMR spectrometer (Palo Alto, CA, USA). Mass spectra (FAB: fast atom bombardment) were recorded on a VG70-250S mass spectrometer (Tokyo, Japan). The absorption and emission spectra were measured using a Jasco V-570 UV-Vis spectrophotometer (Tokyo, Japan) and a Hitachi F-7000 fluorescence spectrophotometer (Tokyo, Japan), respectively. Cyclic voltammetry (CV) was 
performed with a $\mathrm{CH}$ instrument (Austin, TX, USA) at a potential rate of $200 \mathrm{mV} \cdot \mathrm{s}^{-1}$ in a $0.1 \mathrm{M}$ solution of tetrabutylammonium hexafluorophosphate $\left(\mathrm{TBAPF}_{6}\right)$ in dichloromethane. Platinum and $\mathrm{Ag} / \mathrm{AgNO}_{3}$ electrodes were used as counter and reference electrodes, respectively.

\subsection{Synthesis}

\subsubsection{Perylene Bisimide (4)}

A suspension of perylene dianhydride $(900 \mathrm{mg}, 2.3 \mathrm{mmol})$, cyclohexylamine (570 $\mathrm{mg}, 5.8 \mathrm{mmol})$ and acetic acid (500 mg, $8.3 \mathrm{mmol}$ ) in $50 \mathrm{~mL}$ of $N$-methyl-2-pyrrolidinone was stirred at $80{ }^{\circ} \mathrm{C}$ under nitrogen for $8 \mathrm{~h}$. After the mixture was cooled to room temperature, the precipitate was isolated by filtration, washed with $200 \mathrm{~mL}$ of $\mathrm{MeOH}$ and dried in a vacuum. The crude product was purified by silica gel column chromatography with eluent $\mathrm{CH}_{2} \mathrm{Cl}_{2}$ to afford 4 (950 mg, 75\%). Characterization data for 4: ${ }^{1} \mathrm{H}$ NMR (400 MHz, $\left.\mathrm{CDCl}_{3}\right) \delta 8.64(\mathrm{~d}, J=8.0 \mathrm{~Hz}, 4 \mathrm{H}), 8.60(\mathrm{~d}, J=8.0 \mathrm{~Hz}, 4 \mathrm{H}), 5.05$ (m, 2H), $2.58(\mathrm{~m}, 4 \mathrm{H}), 1.91(\mathrm{~m}, 4 \mathrm{H}), 1.76(\mathrm{~m}, 6 \mathrm{H}), 1.36-1.46$ (m, 6H). MS (FAB): m/z (relative intensity) $555\left(\mathrm{M}+\mathrm{H}^{+}, 100\right)$; HRMS: calculated for $\mathrm{C}_{36} \mathrm{H}_{31} \mathrm{~N}_{2} \mathrm{O}_{4}$ 555.2284, found 555.2290.

\subsubsection{Synthesis of 1-Nitroperylene Bisimide (3)}

A mixture of bisimide 4 (900 mg, $1.6 \mathrm{mmol})$, cerium (IV) ammonium nitrate (CAN) (1.2 g, $2.2 \mathrm{mmol})$, nitric acid $(0.1 \mathrm{M}, 3.0 \mathrm{~mL})$ and dichloromethane $(150 \mathrm{~mL})$ was stirred at $25{ }^{\circ} \mathrm{C}$ under $\mathrm{N}_{2}$ for $2 \mathrm{~h}$. The mixture was neutralized with $10 \% \mathrm{KOH}$ and extracted with $\mathrm{CH}_{2} \mathrm{Cl}_{2}$. After the solvent was removed, the crude product was purified by silica gel column chromatography with eluent $\mathrm{CH}_{2} \mathrm{Cl}_{2}$ to afford $3(920 \mathrm{mg}, 95 \%)$. Characterization data for 3: ${ }^{1} \mathrm{H} \mathrm{NMR}\left(400 \mathrm{MHz}, \mathrm{CDCl}_{3}\right) \delta 8.74(\mathrm{~d}$, $J=7.6 \mathrm{~Hz}, 1 \mathrm{H}), 8.62-8.69(\mathrm{~m}, 4 \mathrm{H}), 8.55(\mathrm{~d}, J=8.0 \mathrm{~Hz}, 1 \mathrm{H}), 8.18(\mathrm{~d}, J=7.6 \mathrm{~Hz}, 1 \mathrm{H}), 5.00(\mathrm{~m}, 2 \mathrm{H})$, $2.54(\mathrm{~m}, 4 \mathrm{H}), 1.91(\mathrm{~m}, 4 \mathrm{H}), 1.76(\mathrm{~m}, 6 \mathrm{H}), 1.34-1.47(\mathrm{~m}, 6 \mathrm{H})$; IR (KBr): 2928, 2851, 1700, 1659, 1596, 1539, 1401, 1336, 1262, 1245, 1190, 809, $743 \mathrm{~cm}^{-1}$; MS (FAB): m/z (relative intensity) 600 $\left(\mathrm{M}+\mathrm{H}^{+}, 100\right)$; HRMS: calculated for $\mathrm{C}_{36} \mathrm{H}_{30} \mathrm{O}_{6} \mathrm{~N}_{3} 600.2135$, found 600.2141.

\subsubsection{Synthesis of 1-Aminoperylene Bisimide (2)}

Tin chloride dihydrate $(5.0 \mathrm{~g}, 22 \mathrm{mmol})$ and $3(0.9 \mathrm{~g}, 1.5 \mathrm{mmol})$ were suspended in $50 \mathrm{~mL}$ of THF and stirred for $20 \mathrm{~min}$. The solvent was refluxed with stirring for $2 \mathrm{~h}$ at $80{ }^{\circ} \mathrm{C}$. THF was removed from the rotary evaporator, and the residue was dissolved in ethyl acetate and washed with $10 \% \mathrm{NaOH}$ solution and brine. The organic layer was dried over anhydrous $\mathrm{MgSO}_{4}$, and the filtrate was concentrated under reduced pressure. The crude product was purified by silica gel column chromatography with eluent ethyl acetate/n-hexane (2/3) to afford 2 (680 $\mathrm{mg}, 80 \%)$. Characterization data for 2: ${ }^{1} \mathrm{H}$ NMR (400 MHz, $\left.\mathrm{CDCl}_{3}\right) \delta 8.62(\mathrm{~d}, J=8.0 \mathrm{~Hz}, 1 \mathrm{H}), 8.45(\mathrm{~d}, J=7.6 \mathrm{~Hz}, 1 \mathrm{H}), 8.38$ $(\mathrm{d}, J=8.0 \mathrm{~Hz}, 1 \mathrm{H}), 8.25(\mathrm{~d}, J=7.6 \mathrm{~Hz}, 1 \mathrm{H}), 8.18(\mathrm{~d}, J=8.0 \mathrm{~Hz}, 1 \mathrm{H}), 8.10(\mathrm{~d}, J=8.0 \mathrm{~Hz}, 1 \mathrm{H}), 7.98$ (s, 1H), 5.03, (s, 2H), $4.99(\mathrm{~m}, 2 \mathrm{H}), 2.55(\mathrm{~m}, 4 \mathrm{H}), 1.91(\mathrm{~m}, 4 \mathrm{H}), 1.74(\mathrm{~m}, 6 \mathrm{H}), 1.40-1.46(\mathrm{~m}, 6 \mathrm{H})$; IR (KBr): 3346, 3240, 2926, 1694, 1653, 1372, 1338, 1260, 806, $747 \mathrm{~cm}^{-1}$; MS (FAB): m/z (relative intensity) $570\left(\mathrm{M}+\mathrm{H}^{+}, 100\right)$; HRMS: calculated for $\mathrm{C}_{36} \mathrm{H}_{32} \mathrm{O}_{4} \mathrm{~N}_{3} 570.2393$, found 570.2396. 


\subsubsection{General Procedure for Alkylation (1a-1c)}

A mixture of a solution of 2 (400 mg, $0.70 \mathrm{mmol})$, sodium hydride $(97 \%, 100 \mathrm{mg}, 4.00 \mathrm{mmol})$ and dry THF $(50 \mathrm{~mL})$ was stirred at $0{ }^{\circ} \mathrm{C}$ under $\mathrm{N}_{2}$ for $30 \mathrm{~min}$. Alkyl iodide $(1.60 \mathrm{mmol})$ was then added, and the resulting mixture was stirred for $2 \mathrm{~h}$. The resulting mixture was diluted with $15 \mathrm{~mL}$ of water and extracted with $\mathrm{CH}_{2} \mathrm{Cl}_{2}$. The crude product was purified by silica gel column chromatography with eluent ethyl acetate $/ n$-hexane $(1 / 2)$ to afford $1 \mathbf{a}(\mathbf{1 b}$ or $\mathbf{1 c})$ in an $85 \%$ yield. Characterization data for 1a: ${ }^{1} \mathrm{H}$ NMR $\left(400 \mathrm{MHz}, \mathrm{CDCl}_{3}\right) \delta 9.32(\mathrm{~d}, J=8.0 \mathrm{~Hz}, 1 \mathrm{H}), 8.49-8.53(\mathrm{~m}, 2 \mathrm{H}), 8.48(\mathrm{~s}, 1 \mathrm{H}), 8.31-8.39$ $(\mathrm{m}, 3 \mathrm{H}), 5.02(\mathrm{~m}, 2 \mathrm{H}), 3.40(\mathrm{~m}, 2 \mathrm{H}), 3.06(\mathrm{~m}, 2 \mathrm{H}), 2.55(\mathrm{~m}, 4 \mathrm{H}), 1.90(\mathrm{~m}, 4 \mathrm{H}), 1.62-1.79(\mathrm{~m}, 8 \mathrm{H})$, $1.46(\mathrm{~m}, 4 \mathrm{H}), 1.16-1.30(\mathrm{~m}, 16 \mathrm{H}), 0.77(\mathrm{t}, J=6.4 \mathrm{~Hz}, 6 \mathrm{H}) ;{ }^{13} \mathrm{C}$ NMR $\left(100 \mathrm{MHz}, \mathrm{CDCl}_{3}\right) \delta 164.07$, $164.06,163.99,163.86,150.56,135.47,134.63,133.53,131.41,130.61,129.11,128.95,128.10$, 126.98, 126.94, 126.93, 124.80, 124.03, 123.44, 123.19, 122.76, 122.11, 121.30, 121.19, 54.04, 53.82, 52.55, 31.44, 29.67, 29.18, 29.11, 27.47, 26.89, 26.59, 25.51, 22.52, 13.89; MS (FAB): m/z (relative intensity) $738\left(\mathrm{M}+\mathrm{H}^{+}, 100\right)$; HRMS: calculated for $\mathrm{C}_{48} \mathrm{H}_{56} \mathrm{O}_{4} \mathrm{~N}_{3}$ 738.4271, found 738.4277. Selected data for 1b: ${ }^{1} \mathrm{H}$ NMR $\left(400 \mathrm{MHz}, \mathrm{CDCl}_{3}\right) \delta 9.29(\mathrm{~d}, J=8.0 \mathrm{~Hz}, 1 \mathrm{H}), 8.47-8.52(\mathrm{~m}, 2 \mathrm{H}), 8.46(\mathrm{~s}, 1 \mathrm{H})$, 8.29-8.43 (m, 3H), $5.01(\mathrm{~m}, 2 \mathrm{H}), 3.38(\mathrm{~m}, 2 \mathrm{H}), 3.05(\mathrm{~m}, 2 \mathrm{H}), 2.56(\mathrm{~m}, 4 \mathrm{H}), 1.90(\mathrm{~m}, 4 \mathrm{H}), 1.60-1.77$ $(\mathrm{m}, 6 \mathrm{H}), 1.46(\mathrm{~m}, 6 \mathrm{H}), 1.11-1.20(\mathrm{~m}, 40 \mathrm{H}), 0.82(\mathrm{t}, J=6.7 \mathrm{~Hz}, 6 \mathrm{H}) ;{ }^{13} \mathrm{C}$ NMR $\left(100 \mathrm{MHz}, \mathrm{CDCl}_{3}\right) \delta$ $164.05,164.03,163.97,163.82,150.56,135.44,134.60,133.49,131.40,130.57,129.09,128.93$, $128.05,126.95,126.91,126.89,124.77,124.01,123.42,123.18,122.75,122.00,121.27,121.14$, 54.04, 53.81, 52.49, 31.86, 29.68, 29.56, 29.50, 29.28, 29.19, 29.11, 27.50, 27.21, 26.60, 25.51, 22.64, 14.07; MS (FAB): $\mathrm{m} / \mathrm{z}$ (relative intensity) $906\left(\mathrm{M}+\mathrm{H}^{+}, 100\right.$ ); HRMS: calculated for $\mathrm{C}_{60} \mathrm{H}_{80} \mathrm{O}_{4} \mathrm{~N}_{3}$ 906.6149, found 906.6141. Selected data for 1c: ${ }^{1} \mathrm{H}$ NMR $\left(400 \mathrm{MHz}, \mathrm{CDCl}_{3}\right) \delta 9.37(\mathrm{~d}, J=8.0 \mathrm{~Hz}$, $1 \mathrm{H}), 8.53-8.56(\mathrm{~m}, 2 \mathrm{H}), 8.48(\mathrm{~s}, 1 \mathrm{H}), 8.38-8.43(\mathrm{~m}, 3 \mathrm{H}), 5.03(\mathrm{~m}, 2 \mathrm{H}), 3.44(\mathrm{~m}, 2 \mathrm{H}), 3.07(\mathrm{~m}, 2 \mathrm{H})$, $2.56(\mathrm{~m}, 4 \mathrm{H}), 1.91(\mathrm{~m}, 4 \mathrm{H}), 1.63-1.73(\mathrm{~m}, 6 \mathrm{H}), 1.47(\mathrm{~m}, 6 \mathrm{H}), 1.12-1.20(\mathrm{~m}, 64 \mathrm{H}), 0.85(\mathrm{t}, J=6.7 \mathrm{~Hz}$, $6 \mathrm{H}) ;{ }^{13} \mathrm{C} \mathrm{NMR}\left(100 \mathrm{MHz}, \mathrm{CDCl}_{3}\right) \delta 164.15,164.09,164.05,163.88,150.54,135.56,134.75,133.63$, $131.51,130.70,129.19,129.04,128.17,127.03,124.87,124.06,123.50,123.46,123.44,123.22$, $122.82,122.22,121.34,121.23,54.03,53.82,52.61,31.91,29.67,29.64,29.58,29.51,29.34,29.27$, 29.19, 29.12, 27.54, 27.22, 26.59, 25.51, 22.67, 14.09; MS (FAB): m/z (relative intensity) 1074 $\left(\mathrm{M}+\mathrm{H}^{+}, 100\right)$; HRMS: calculated for $\mathrm{C}_{72} \mathrm{H}_{104} \mathrm{O}_{4} \mathrm{~N}_{3}$ 1074.8027, found 1074.8019 .

\section{Results and Discussion}

\subsection{Synthesis}

Scheme 1 depicts the chemical structures and synthetic routes of asymmetric amino-substituted PBIs (1a-1c). Synthesis starts from an imidization of perylene dianhydride (5) by reaction with cyclohexylamine. The mono-nitration can then be achieved by a reaction of perylene bisimide (4) with cerium (IV) ammonium nitrate (CAN) and $\mathrm{HNO}_{3}$ under ambient temperature for $2 \mathrm{~h}$ [58], giving 3 in high yields of $c a .90 \%$. The reduction of 1-nitroperylene bisimide (3) by tin (II) chloride dihydrate $\left(\mathrm{SnCl}_{2} \cdot 2 \mathrm{H}_{2} \mathrm{O}\right)$ in refluxing THF obtained 1-aminoperylene bisimide (2). Finally, three highly soluble perylene bisimide derivatives (1a-1c) with different $n$-alkyl chain lengths $(n=6,12$, or 18, Figure 1$)$ can be prepared by the alkylation of 2 with the corresponding alkyl halides. The asymmetric structure of 1-(N,N-dialkylamino)perylene bisimides $(\mathbf{1 a}-\mathbf{1 c})$ can be verified by the presence of seven signals 
(one singlet and six doublet signals) at $\delta$ 8.3-9.4 ppm in the ${ }^{1} \mathrm{H}$ NMR spectrum, which indicates that there are seven different kinds of protons in the perylene core (Figure 2). Detailed synthetic procedures and product characterization are provided in the Experimental Section.

Scheme 1. The synthetic route for $\mathbf{1 a}-\mathbf{1 c}$.
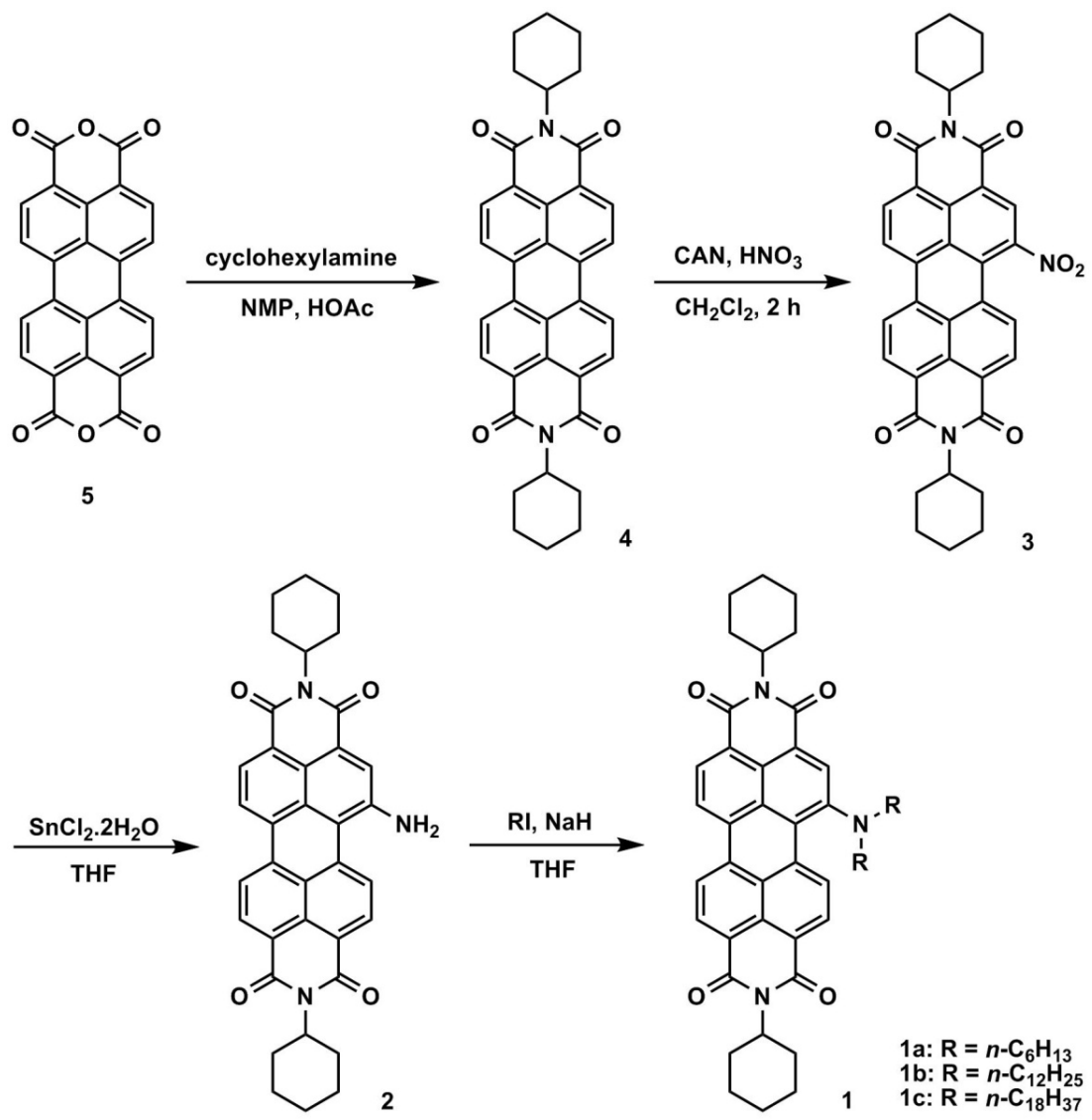

Figure 1. Solubility of $\mathbf{1 a}-\mathbf{1 c}$ in dichloromethane $\left(25^{\circ} \mathrm{C}\right)$.

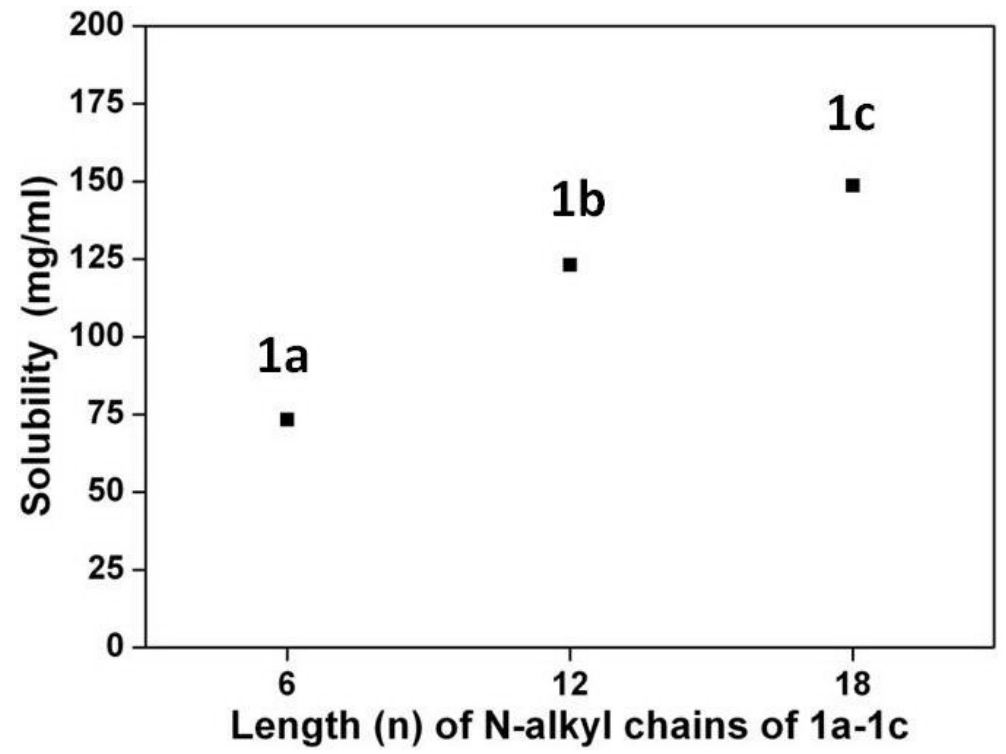


Figure 2. ${ }^{1} \mathrm{H} \mathrm{NMR}\left(400 \mathrm{MHz}, \mathrm{CDCl}_{3}\right)$ spectra of $\mathbf{1 a}$.

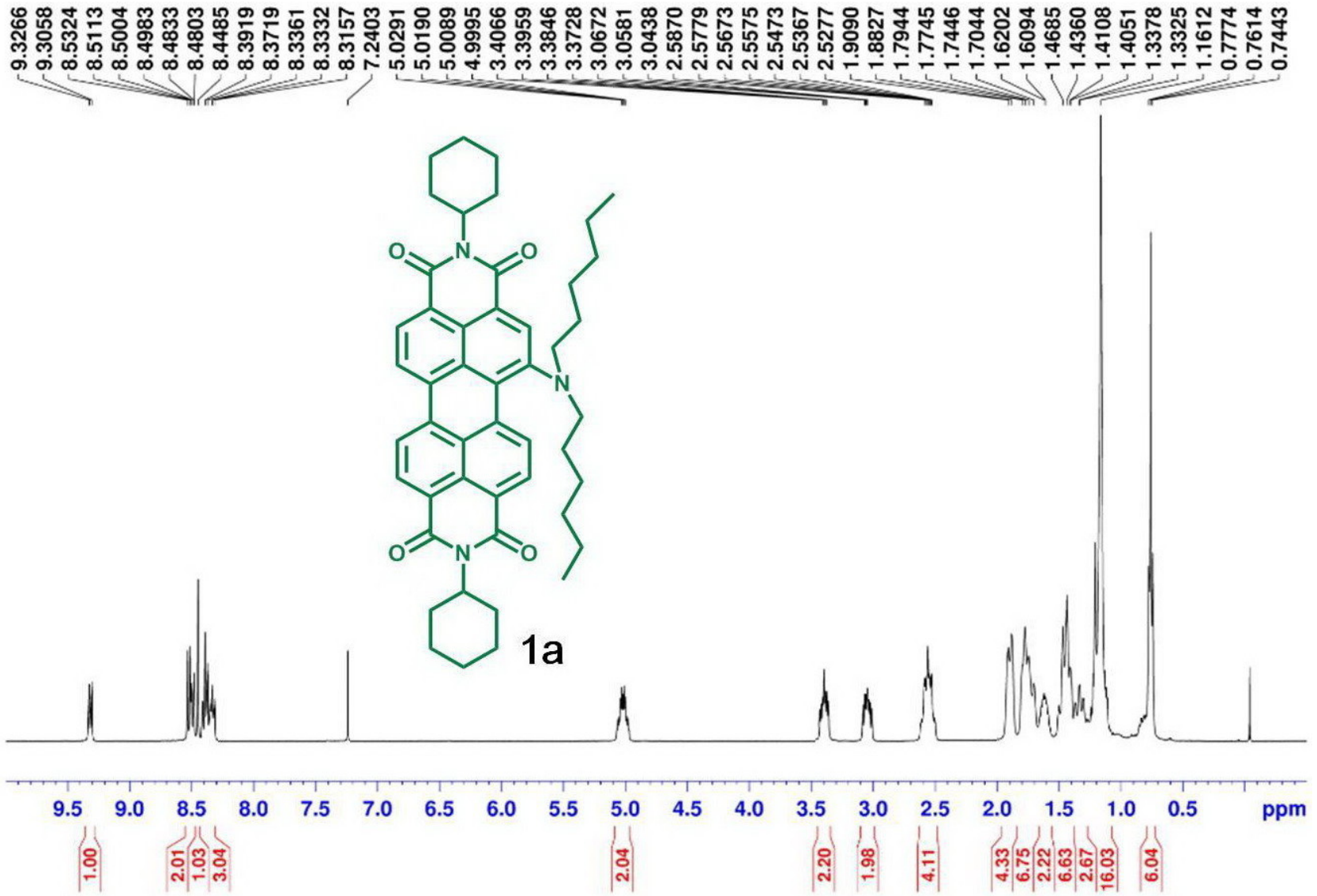

\subsection{Optical Properties}

Figure 3 shows the steady-state absorption spectra of the green dye 1a in solvents of varying polarity, and pertinent photophysical data for 1a-1c are summarized in Table 1. The spectra of all of the amino-substituted PBIs (1a-1c and 2) are dominated by broad absorption bands that cover a large part of the visible spectrum $(350-750 \mathrm{~nm})$. These broad bands are representative for perylene bisimide derivatives $N$-substituted at the bay-core positions, due to charge transfer absorption [78]. The longest wavelength absorption bands of 1a-1c in various solvents are found to be almost the same, which indicates that different $N$-alkyl chain lengths do not significantly affect the band gap energies. Moreover, the longest wavelength absorption band of 1a-1c exhibits a red shift when the solvent polarity increases (Table 1), which is consistent with the previous studies [76].

The steady-state emission spectra of $\mathbf{1 a}$ in different solvents of varying polarity are shown in Figure 4. Unlike the small shift in absorption spectra, the fluorescence spectra of 1a-1c are largely red-shifted if there is any increase of the solvent polarity, which indicates strong intramolecular charge transfer (ICT) characteristics for the excited states of the compounds, 1a-1c (Table 1). We further used the well-established fluorescence solvatochromic shift method [87] to measure the stabilization of the excited states of 1a-1c. The change of magnitudes for dipole moments between ground and excited states, i.e., $\Delta \mu=\left|\overrightarrow{\mu_{e}}-\overrightarrow{\mu_{s}}\right|$, can be estimated by the Lippert-Mataga equation and expressed as: 


$$
\bar{v}_{a}-\bar{v}_{f}=\frac{2}{h c}\left(\mu_{e}-\mu_{g}\right)^{2} a_{0}{ }^{-3} \Delta f+\text { const }
$$

where $h$ is the Planck constant, $c$ is the speed of light, $a_{0}$ denotes the cavity radius in which the solute resides, $\bar{v}_{a}-\bar{v}_{f}$ is the Stokes shift of the absorption and emission peak maximum and $\Delta f$ is the orientation polarizability defined as:

$$
\Delta f=f(\varepsilon)-f\left(n^{2}\right)=\frac{\varepsilon-1}{2 \varepsilon+1}-\frac{n^{2}-1}{2 n^{2}+1}
$$

The plot of the Stokes shift $\bar{v}_{a}-\bar{v}_{f}$ as a function of $\Delta f$ is sufficiently linear for 1a-1c (Figure 5). Accordingly, $\Delta \mu=\left|\overrightarrow{\mu_{e}}-\overrightarrow{\mu_{g}}\right|$ values can be calculated as $9.0 \mathrm{D}, 11.7 \mathrm{D}$ and $12.8 \mathrm{D}$ for 1a-1c. These values indicate that the alkylamino-substituted PBIs (1a-1c) have larger dipole moment changes than that (7.4 D) of the amino-substituted compound (2).

Figure 3. Normalized absorption spectra of 1a in cyclohexane (black line), diethyl ether (cyan line), ethyl acetate (blue line), dichloromethane (green line) and acetonitrile (red line).

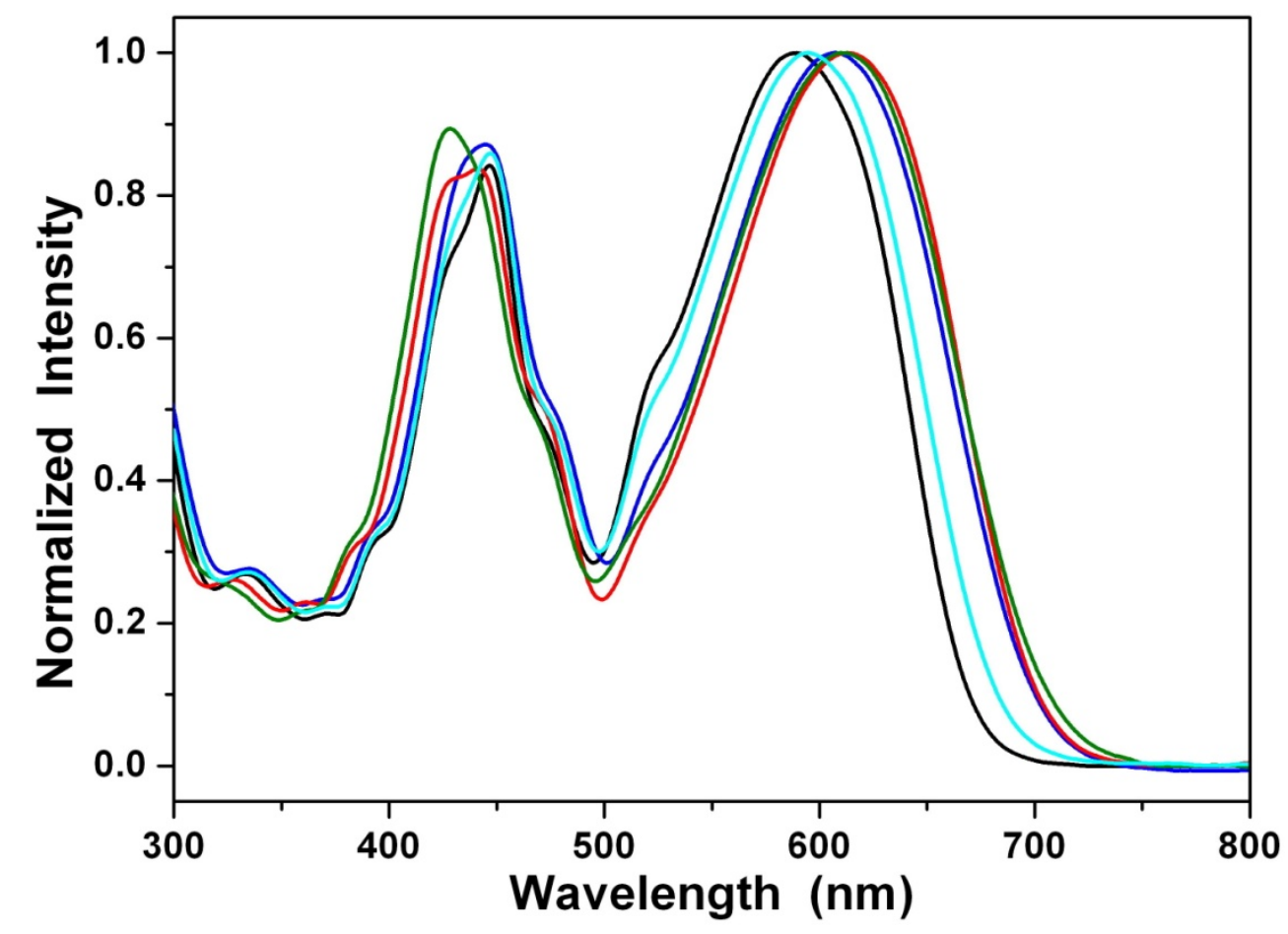

Table 1. Summary of optical absorption and emission properties of $\mathbf{1 a}-\mathbf{1 c}$ in various solvents.

\begin{tabular}{ccccc}
\hline $\mathbf{1 a} / \mathbf{1 b} / \mathbf{1 c}$ & $\boldsymbol{\lambda}_{\text {abs }}(\mathbf{n m})^{\mathbf{a}}$ & $\boldsymbol{\lambda}_{\text {em }}(\mathbf{n m})^{\mathbf{a}}$ & Stokes shift $(\mathbf{n m})$ & $\mathbf{\Phi}^{\mathbf{b}} \times \mathbf{1 0}^{\mathbf{2}}$ \\
\hline cyclohexane & $589 / 589 / 589$ & $678 / 675 / 677$ & $89 / 86 / 88$ & $1.88 / 2.70 / 2.57$ \\
diethyl ether & $597 / 601 / 597$ & $700 / 700 / 701$ & $103 / 99 / 104$ & $0.47 / 0.58 / 0.45$ \\
ethyl acetate & $608 / 610 / 610$ & $720 / 722 / 721$ & $112 / 112 / 111$ & $0.24 / 0.31 / 0.29$ \\
dichloromethane & $610 / 611 / 612$ & $724 / 726 / 726$ & $114 / 115 / 114$ & $0.20 / 0.29 / 0.26$ \\
acetonitrile & $613 / 614 / 614$ & $738 / 737 / 736$ & $125 / 123 / 122$ & $0.12 / 0.19 / 0.17$ \\
\hline
\end{tabular}

${ }^{\text {a }}$ Measured at $2 \times 10^{-5} \mathrm{M} ;{ }^{b}$ determined with $N, N^{\prime}$-dioctyl-3,4,9,10-perylenedicarboximide as the reference [31]. 
Figure 4. Normalized emission spectra of 1a in cyclohexane (black line), diethyl ether (cyan line), ethyl acetate (blue line), dichloromethane (green line) and acetonitrile (red line).

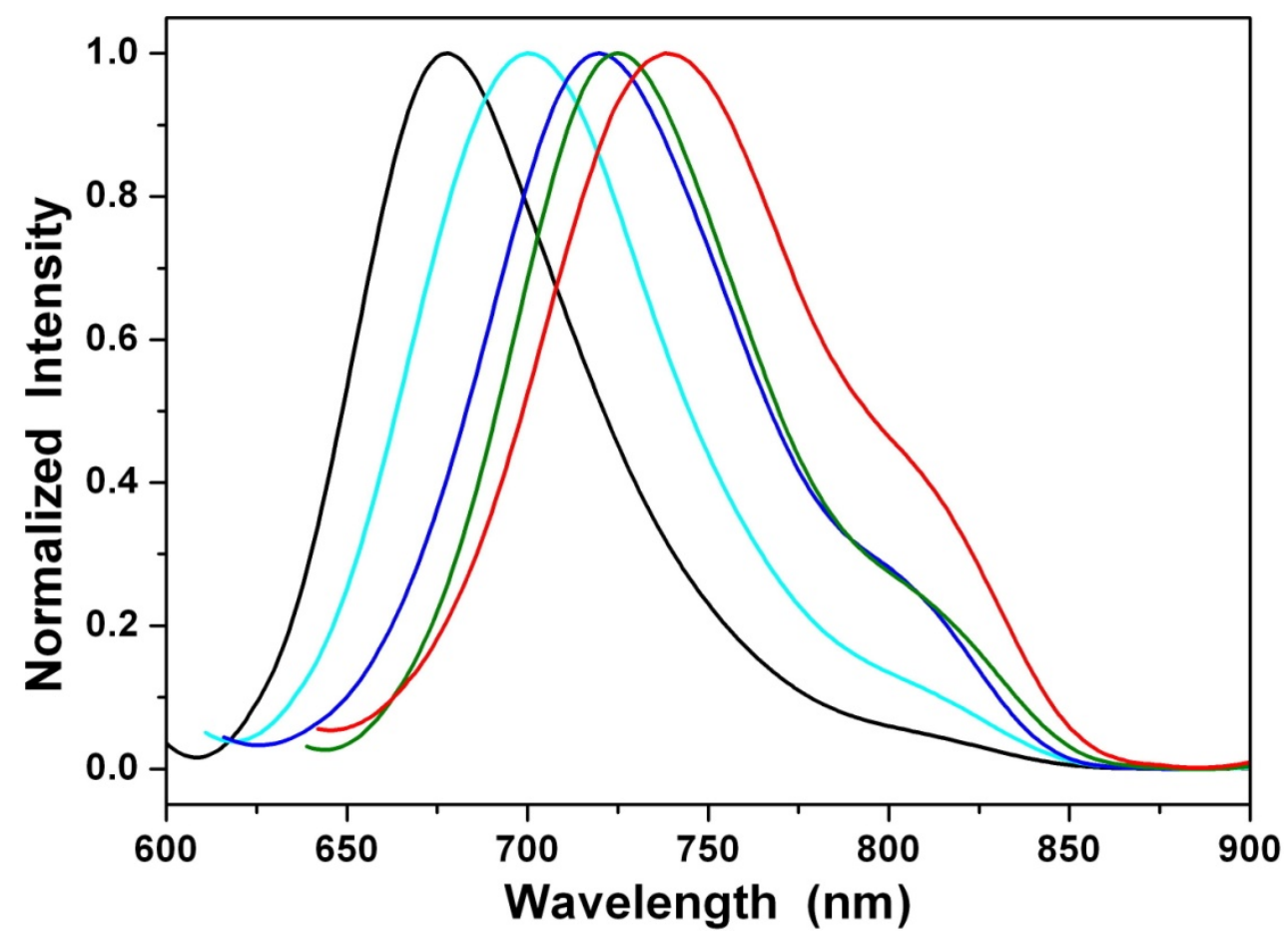

Figure 5. Lippert-Mataga plots for 1a (blue line), 1b (green line) and 1c (red line). The solvents are (1) cyclohexane, (2) diethyl ether, (3) ethyl acetate, (4) dichloromethane and (5) acetonitrile.

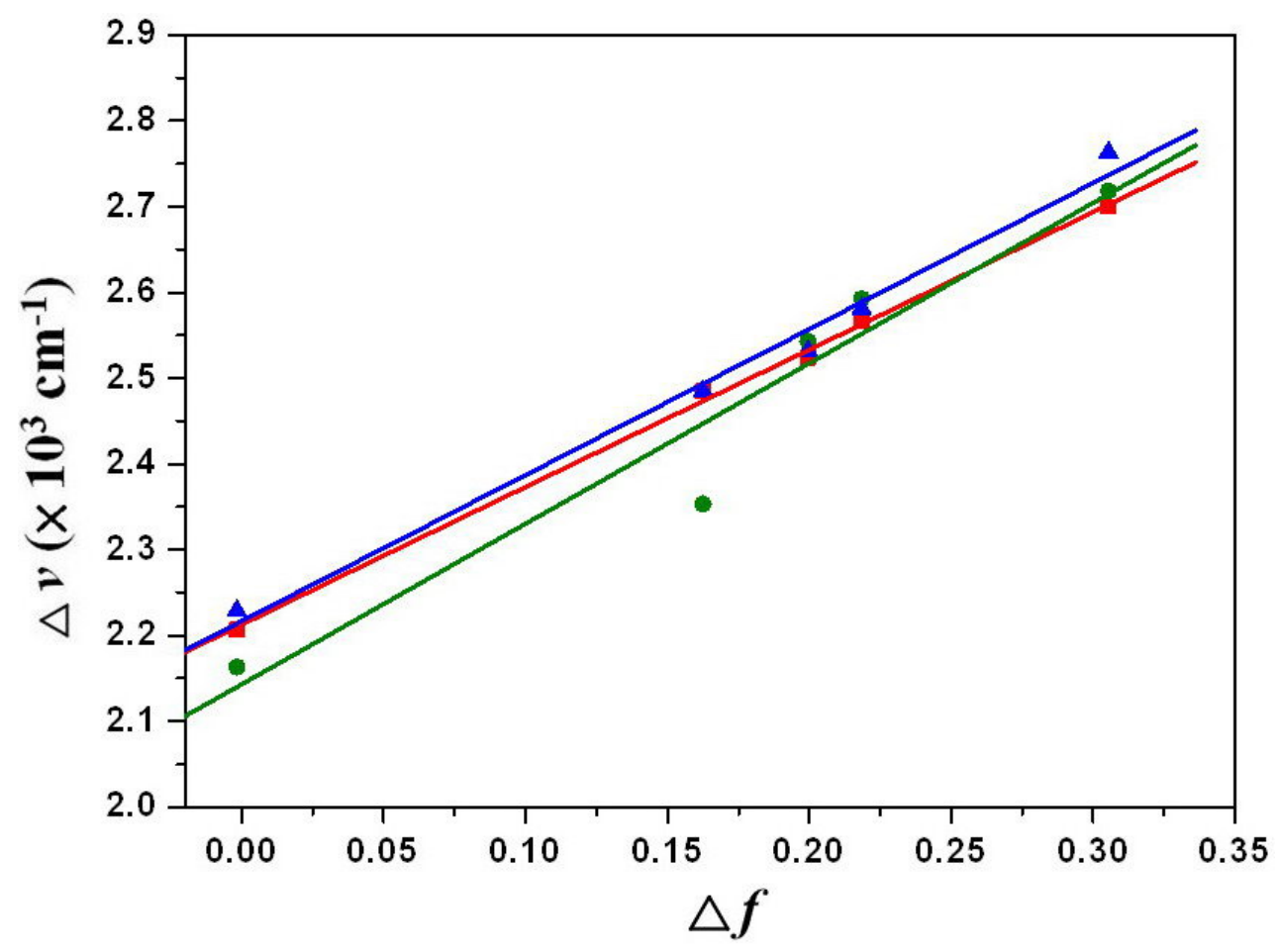




\subsection{Quantum Chemistry Computation}

To gain more insight into the molecular structures and electronic properties of $\mathbf{1 - 4}$, quantum chemical calculations were performed using density functional theory (DFT) at the B3LYP/6-31G** level $[88,89]$. The highest occupied molecular orbitals (HOMOs) and the lowest unoccupied molecular orbitals (LUMOs) of 1a and $\mathbf{2}$ are shown in Figure 6. The HOMO of all amino-substituted PBIs (1a-1c and 2) is delocalized mainly on the amino group and the perylene core, while the LUMO is extended from the central perylene core to the bisimide groups. The calculated and experimental parameters for perylene bisimide derivatives 1-4 are summarized in Table 2. It is apparent that the HOMO/LUMO energy levels of $\mathbf{1 a - 1 c}$ and $\mathbf{2}$ are higher than those of $\mathbf{3}$ and $\mathbf{4}$; this can be explained by the fact that the amino (nitro) substituent is a strong electron-donating (electron-withdrawing) group and hence increases (decreases) both the HOMO and LUMO energy levels. Additionally, the relative band gap energies estimated from the longest absorption maxima of 1-4 are in good agreement with the theoretical calculations (Table 2).

Figure 6. Calculated frontier orbitals for 1a and 2. The upper structures show the LUMOs and the lower ones show the HOMOs.

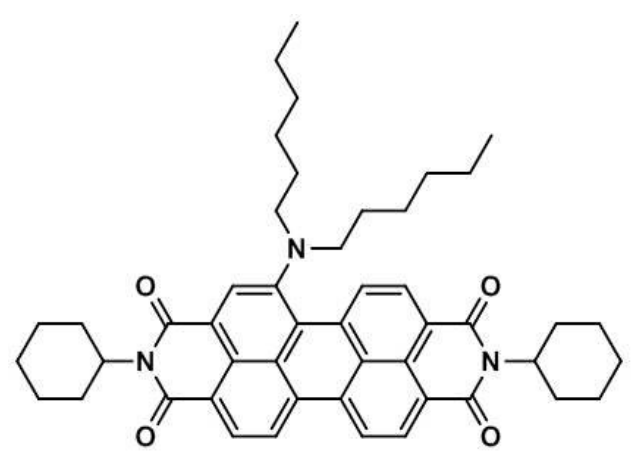

$1 \mathrm{a}$
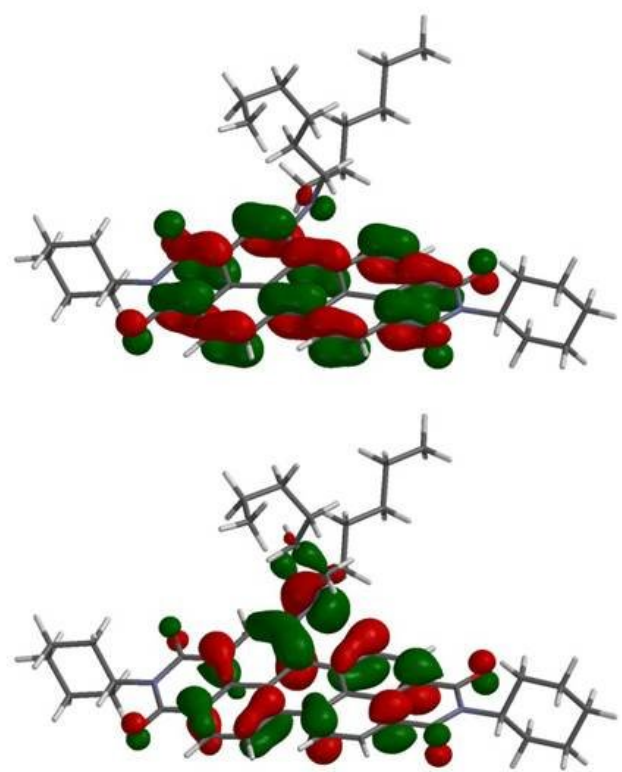

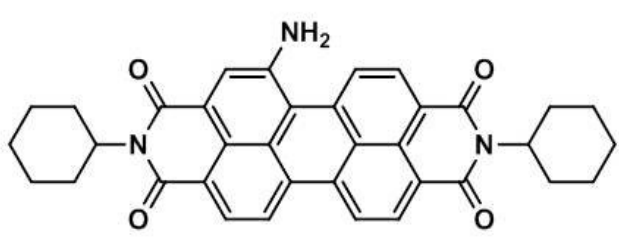

2
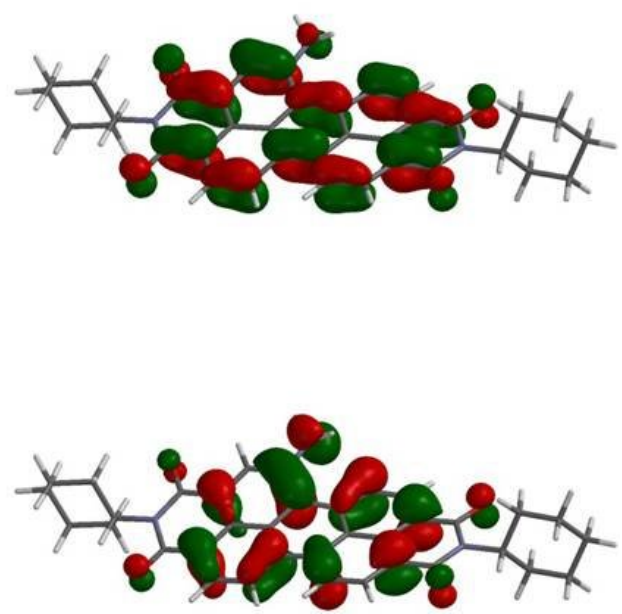

DFT calculations also show that the ground-state geometries of the perylene core have different core twist angles (Figure 7), i.e., approximate dihedral angles between the two naphthalene subunits 
attached to the central benzene ring; these are $\sim 9.40^{\circ}$ and $\sim 13.43^{\circ}$ for $\mathbf{1 a}, \sim 9.42^{\circ}$ and $\sim 13.45^{\circ}$ for $\mathbf{1 b}$, $\sim 9.45^{\circ}$ and $\sim 13.49^{\circ}$ for $1 \mathbf{c}, \sim 9.23^{\circ}$ and $\sim 17.49^{\circ}$ for $\mathbf{2}$ and $\sim 7.89^{\circ}$ and $\sim 15.87^{\circ}$ for 3 (Table 2); and all are larger than those of $4\left(\sim 0.00^{\circ}\right)$. As a whole, the core twist angles of the mono-substituted PBIs (1-3) are larger than that of the non-substituted compound (4).

Figure 7. DFT (B3LYP/6-31G**) geometry-optimized structures of 1a (left) and 2 (right) shown with the view along the long axis. For computational purposes, methyl groups replace the cyclohexyl groups at the imide positions.
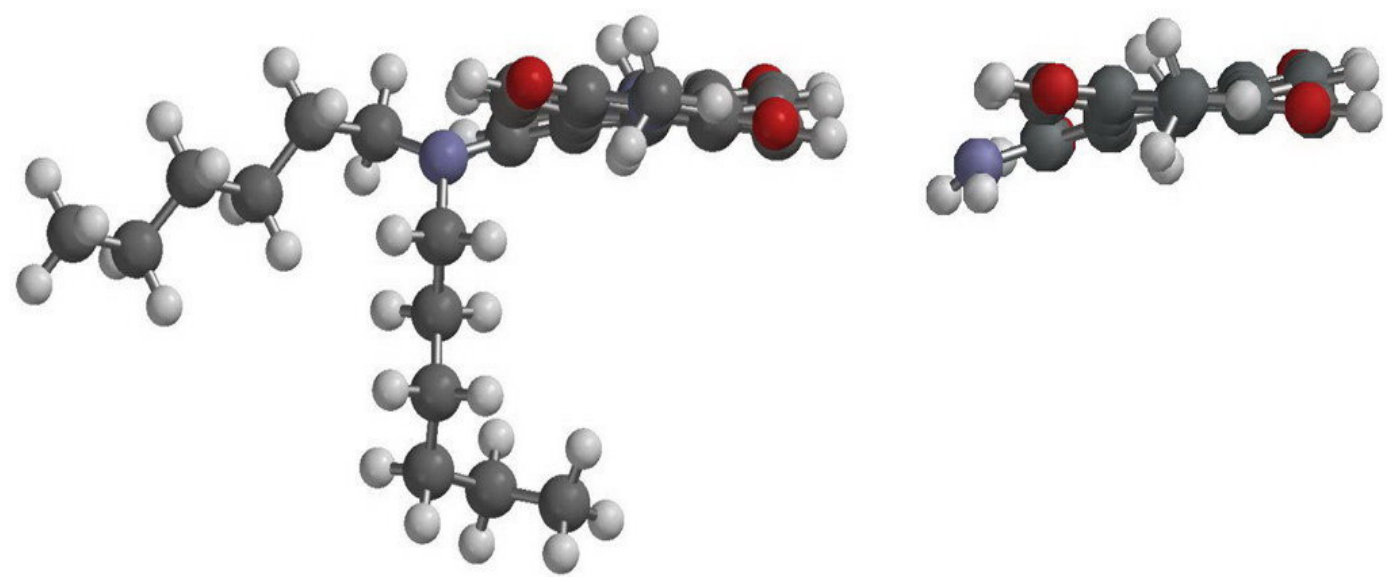

Table 2. Calculated and experimental parameters for perylene bisimide derivatives.

\begin{tabular}{cccccccc}
\hline Compound & HOMO $^{\mathbf{a}}$ & LUMO $^{\mathbf{a}}$ & $\boldsymbol{E}_{\mathbf{g}}{ }^{\mathbf{a}}$ & $\boldsymbol{E}_{\mathbf{g}}{ }^{\mathbf{b}}$ & $\boldsymbol{\mu}_{\mathbf{g}}{ }^{\mathbf{c}}$ & $\boldsymbol{\mu}_{\mathbf{e}}{ }^{\mathbf{d}}$ & Twisting angle ( $\left.^{\circ}\right)$ \\
\hline $\mathbf{1 a}$ & -5.48 & -3.19 & 2.29 & 2.11 & 3.5 & 12.5 & $9.40,13.43$ \\
$\mathbf{1 b}$ & -5.48 & -3.19 & 2.29 & 2.11 & 3.6 & 15.3 & $9.42,13.45$ \\
$\mathbf{1 c}$ & -5.47 & -3.19 & 2.28 & 2.11 & 3.8 & 16.6 & $9.45,13.49$ \\
$\mathbf{2}$ & -5.62 & -3.21 & 2.41 & 2.24 & 2.7 & 10.1 & $9.23,17.49$ \\
$\mathbf{3}$ & -6.25 & -3.84 & 2.41 & 2.39 & - & - & $7.89,15.87$ \\
$\mathbf{4}$ & -5.94 & -3.46 & 2.48 & 2.38 & - & - & $0.00,0.00$ \\
\hline
\end{tabular}

${ }^{\mathrm{a}}$ Calculated by DFT/B3LYP (in eV); ${ }^{\mathrm{b}}$ at absorption maxima $\left(E_{\mathrm{g}}=1240 / \lambda_{\max }\right.$, in eV); ${ }^{\mathrm{c}}$ ground-state dipole moment (calculated by DFT/B3LYP, in Debye); ${ }^{\mathrm{d}}$ excited-state dipole moment (in Debye).

\subsection{Electrochemical Properties}

The cyclic voltammograms of 1a-1c are illustrated in Figure 8. These dyes undergo two quasi-reversible one-electron oxidations and two quasi-reversible one-electron reductions in dichloromethane, which clearly indicates that all of these processes can be attributed to the successive addition or removal of electrons to the orbitals. Table 3 summarizes the redox potentials and the HOMO and LUMO energy levels estimated from cyclic voltammetry (CV) for 1-4. It appears that both the first oxidation and the first reduction potentials can be shifted toward more negative (positive) values by introducing strongly electron-donating (electron-withdrawing) groups onto the perylene core, while both the HOMO and LUMO energy levels increase (decrease) with the trend. 
Figure 8. The cyclic voltammograms of $\mathbf{1 a}$ (blue line), $\mathbf{1 b}$ (green line) and 1c (red line) measured in dichloromethane solution with ferrocenium/ferrocene as an internal standard, at $200 \mathrm{mV} \cdot \mathrm{s}^{-1}$.

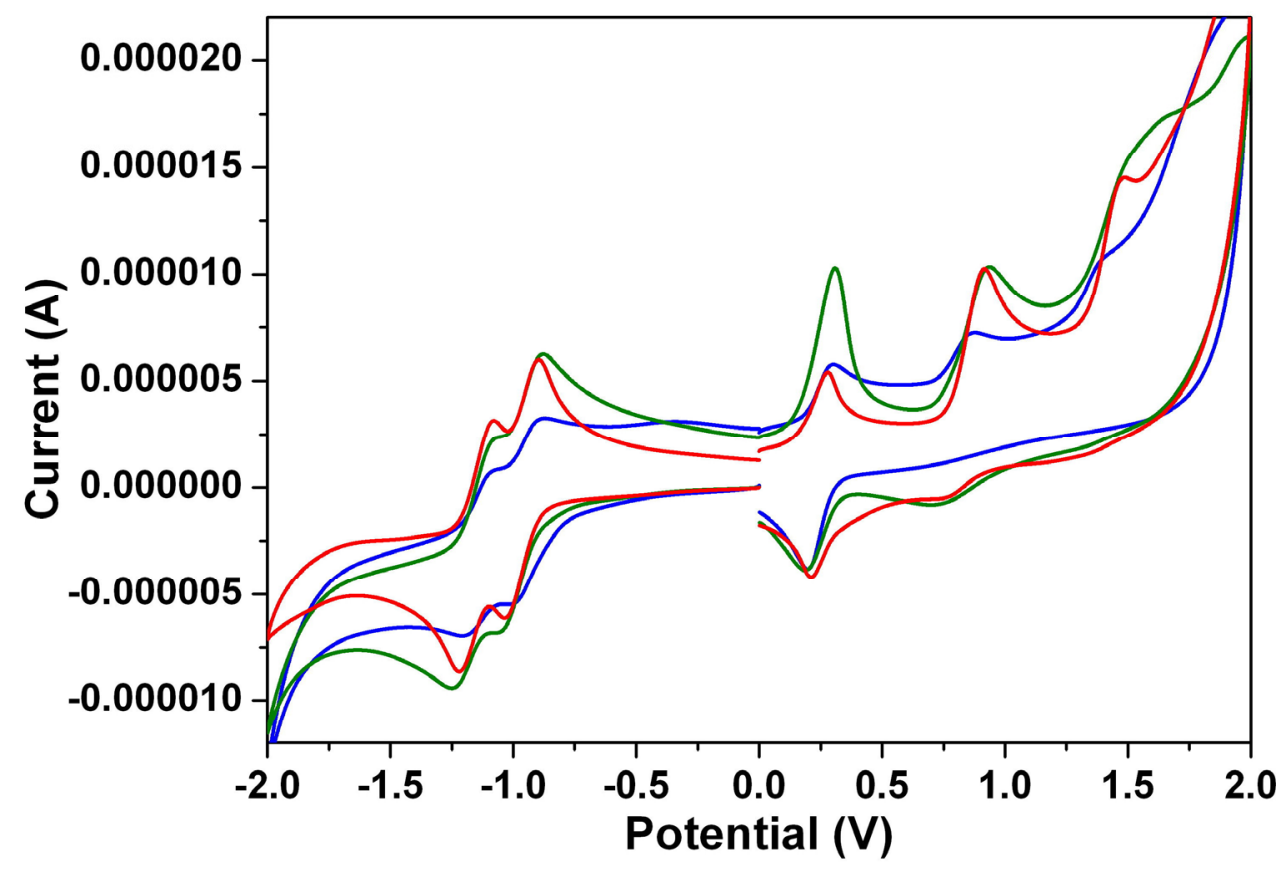

Table 3. Summary of half-wave redox potentials, HOMO and LUMO energy levels for perylene bisimide derivatives.

\begin{tabular}{|c|c|c|c|c|c|c|}
\hline Compound & $E_{1 / 2}^{+a}$ & $E_{1 / 2}^{2+}{ }^{a}$ & $E_{1 / 2}^{-a}$ & $E_{1 / 2}^{2-}$ & HOMO $^{b}$ & LUMO $^{\text {b }}$ \\
\hline $1 \mathrm{a}$ & 0.85 & 1.32 & -1.02 & -1.17 & -5.47 & -3.36 \\
\hline $1 b$ & 0.86 & 1.34 & -1.05 & -1.21 & -5.48 & -3.37 \\
\hline 1c & 0.84 & 1.33 & -1.01 & -1.20 & -5.46 & -3.35 \\
\hline 2 & 0.97 & 1.36 & -0.97 & -1.09 & -5.57 & -3.33 \\
\hline $3^{c}$ & - & - & -0.19 & -0.51 & -6.64 & -4.25 \\
\hline $4^{c}$ & - & - & -0.46 & -0.76 & -6.36 & -3.98 \\
\hline
\end{tabular}

${ }^{a}$ Measured in a solution of $0.1 \mathrm{M}$ tetrabutylammonium hexafluorophosphate $\left(\mathrm{TBAPF}_{6}\right)$ in dichloromethane (in V); ${ }^{\mathrm{b}}$ calculated from $E_{\mathrm{HOMO}}=-4.88-\left(E_{\mathrm{oxd}}-E_{\mathrm{Fc} / \mathrm{Fc}+}\right), E_{\mathrm{LUMO}}=E_{\mathrm{HOMO}}+E_{\mathrm{g}} ;^{\mathrm{c}}$ estimated versus vacuum level from $E_{\mathrm{LUMO}}=-4.44-E_{(1)}$.

\subsection{Stacking Behaviors of Dyes in Solution and Solid State}

Figure 9 shows the absorption spectra recorded for thin drop-cast films of 1a-1c. The shapes of the absorption spectra of 1a-1c in solid state and in solution are found to be virtually the same, in view of the wavelength range and peak positions. The results clearly show that it is difficult for compounds 1a-1c to form $\pi$-aggregates; this can be explained by the fact that the long alkyl chains can efficiently prevent aggregation. In contrast, the absorption spectrum of the drop-cast film chromophore 2 is red-shifted, as well as broadened compared to its respective spectrum in nonpolar cyclohexane, which can be attributed mainly to intermolecular $\pi-\pi$ interactions in the solid state [76]. 
Figure 9. Normalized absorption spectra of $\mathbf{1 a}$ (blue line), $\mathbf{1 b}$ (green line) and 1c (red line) in neat film.

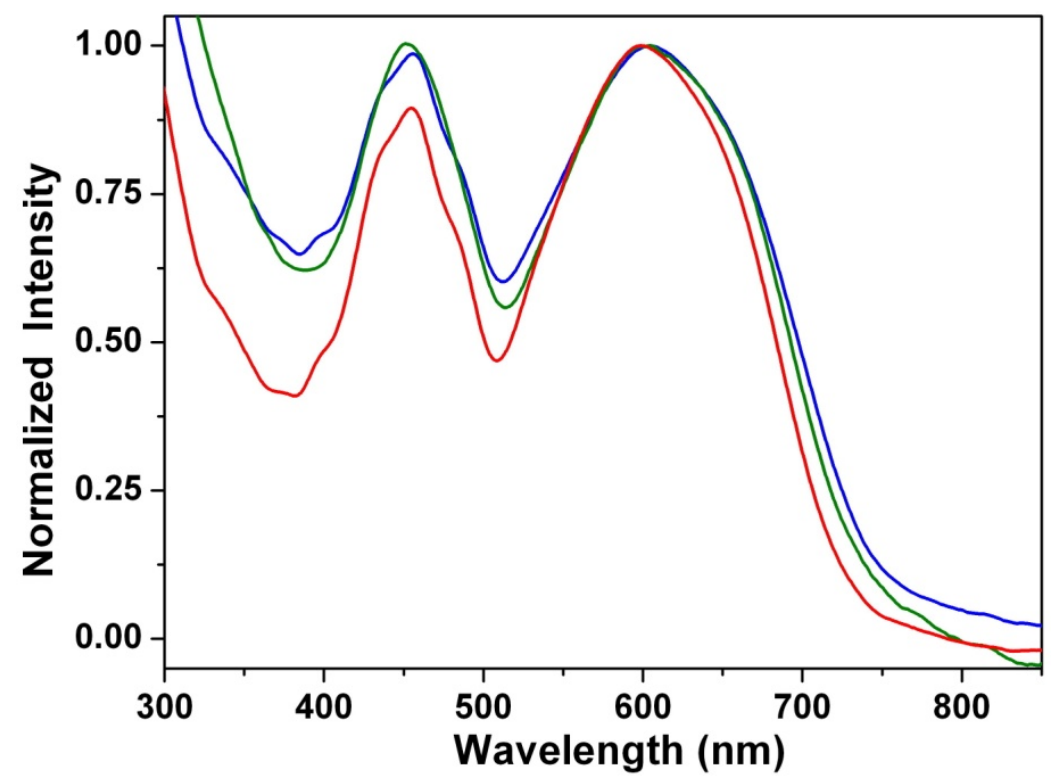

\subsection{Influence of the Acidic Condition on the Optical Properties of Dyes}

The effects of strongly acidic conditions on the absorption and emission spectra of 1a were also examined. Figure 10 shows the absorption and emission spectra of $\mathbf{1 a}$ in concentrated $\mathrm{HCl}$. The absorption spectrum of $\mathbf{1 a}$ in such an acidic condition loses its typical absorption band over $590 \mathrm{~nm}$ and, instead, shows non-substituted PBIs centered at $520 \mathrm{~nm}$, as also observed by the red color of the analyzed solution. The most likely explanation is that the nitrogen atom on the bay-core is protonated in this medium, so that charge transfer is no longer possible (Scheme 2). Moreover, the protonation-dependent change of color is completely reversible.

Figure 10. The absorption (black line) and emission (red line) spectra of $\mathbf{1 a}$ in concentrated $\mathrm{HCl}$.

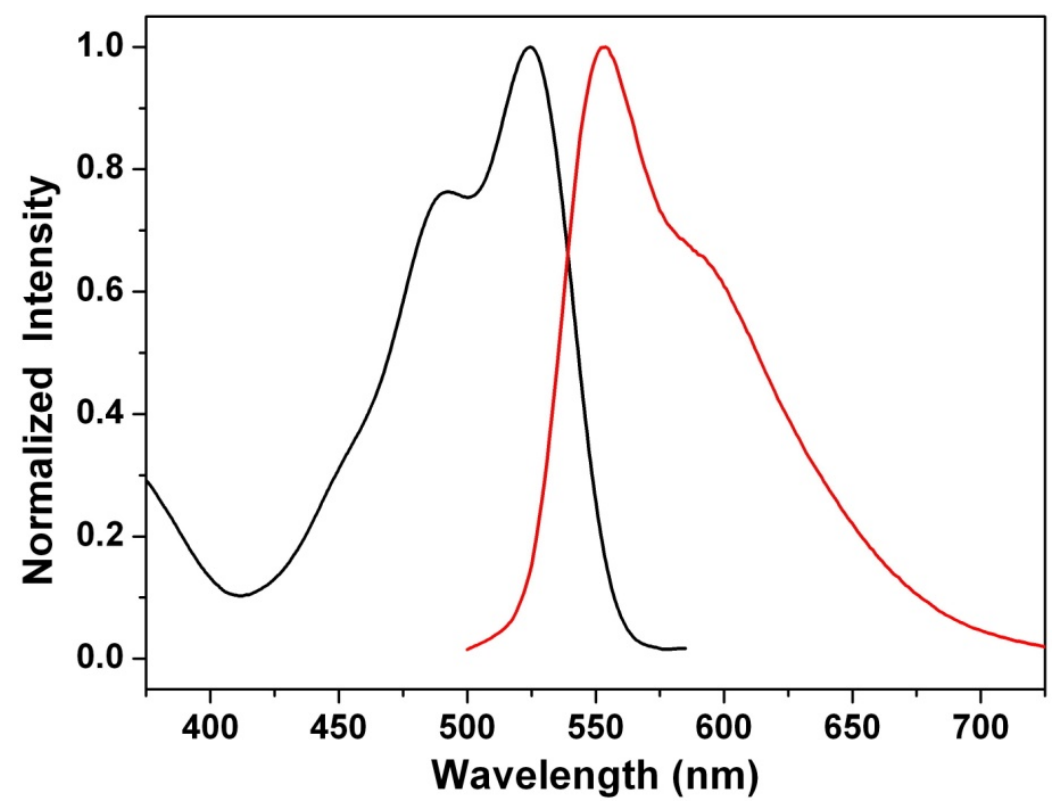


Scheme 2. One of the possible resonance structures for 1a, explaining the disappearance of the charge transfer absorption band in concentrated $\mathrm{HCl}$.
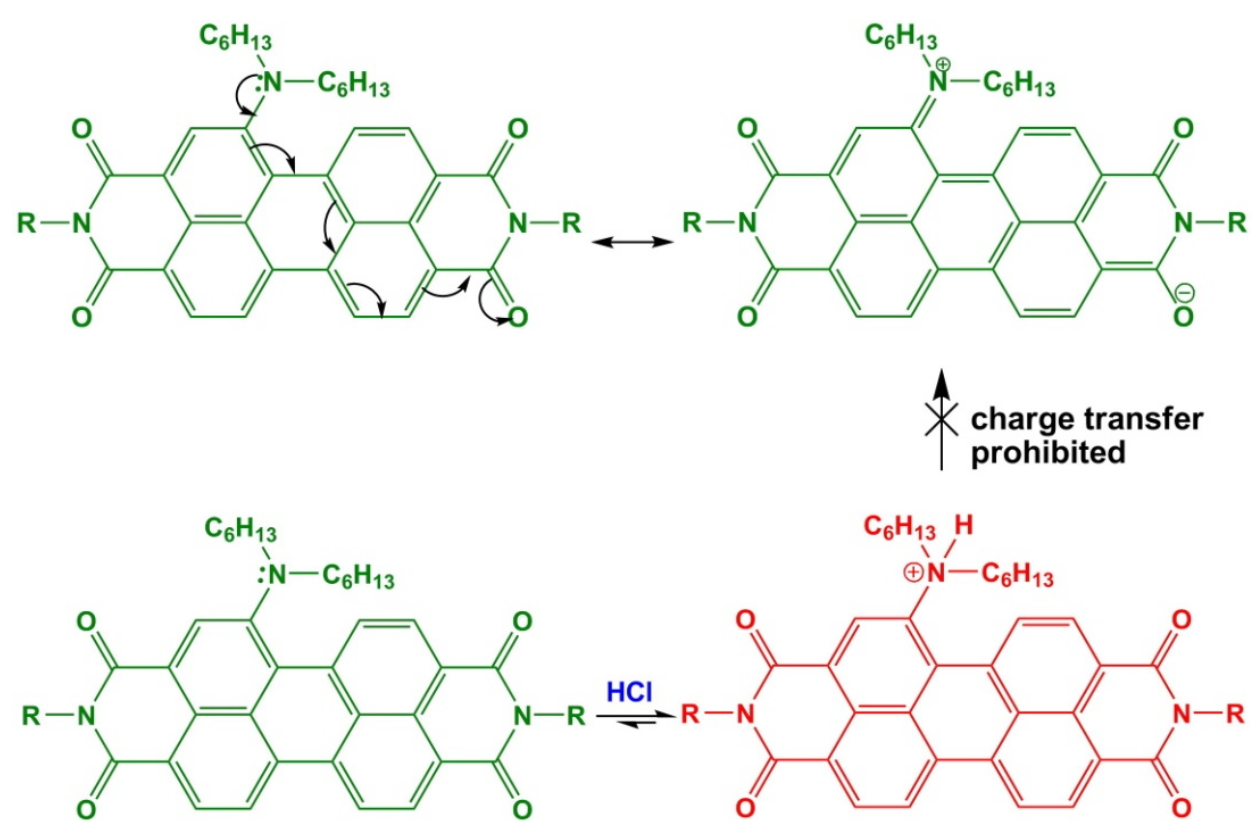

\section{Conclusions}

We have successfully synthesized three green dyes based on alkylamino-substituted PBIs (1a-1c). All of the new PBI dyes are soluble in most organic polar and nonpolar solvents. These molecules show a unique charge transfer emission in the near-infrared region, and the associated peaks exhibit solvatochromism. Upon excitation, they show larger dipole moment changes than that of 2; the dipole moments of these compounds have been estimated using the Lippert-Mataga equation. Furthermore, they display reversible redox properties, as well as good optical stability. Research on their applications to organic photovoltaic cells is currently in progress.

\section{Acknowledgments}

The project was supported by the Ministry of Science and Technology (MOST 103-2113-M-035-001) in Taiwan. The authors appreciate the Precision Instrument Support Center of Feng Chia University for providing the fabrication and measurement facilities.

\section{Author Contributions}

Che-Wei Chang designed and performed the experiments. Hsing-Yang Tsai measured and analysed the data. Kew-Yu Chen supervised the project.

\section{Conflicts of Interest}

The authors declare no conflict of interests. 


\section{References}

1. Jones, B.A.; Ahrens, M.J.; Yoon, M.H.; Facchetti, A.; Marks, T.J.; Wasielewski, M.R. High-mobility air-stable $n$-type semiconductors with processing versatility: Dicyanoperylene3,4:9,10-bis(dicarboximides). Angew. Chem. Int. Ed. 2004, 43, 6363-6366.

2. Kim, F.S.; Guo, X.; Watson, M.D.; Jenekhe, S.A. High-mobility ambipolar transistors and high-gain inverters from a donor-acceptor copolymer semiconductor. Adv. Mater. 2009, 21, 1-5.

3. Würthner, F.; Stolte, M. Naphthalene and perylene diimides for organic transistors. Chem. Commun. 2011, 47, 5109-5115.

4. Reghu, R.R.; Bisoyi, H.K.; Grazulevicius, J.V.; Anjukandi, P.; Gaidelis, V.; Jankauskas, V. Air stable electron-transporting and ambipolar bay substituted perylene bisimides. J. Mater. Chem. 2011, 21, 7811-7819.

5. Zaumseil, J.; Sirringhaus, H. Electron and ambipolar transport in organic field-effect transistors. Chem. Rev. 2007, 107, 1296-1323.

6. Locklin, J.; Li, D.; Mannsfeld, S.C.B.; Borkent, E.J.; Meng, H.; Advincula, R.; Bao, Z. Organic thin film transistors based on cyclohexyl-substituted organic semiconductors. Chem. Mater. 2005, 17, 3366-3374.

7. Kozma, E.; Kotowski, D.; Catellani, M.; Luzzati, S.; Famulari, A.; Bertini, F. Synthesis and characterization of new electron acceptor perylene diimide molecules for photovoltaic applications. Dyes Pigm. 2013, 99, 329-338.

8. Li, J.; Dierschke, F.; Wu, J.; Grimsdale, A.C.; Müllen, K. Poly(2,7-carbazole) and perylene tetracarboxydiimide: A promising donor/acceptor pair for polymer solar cells. J. Mater. Chem. 2006, 16, 96-100.

9. Dinçalp, H.; Aşkar, Z.; Zafer, C.; İçli, S. Effect of side chain substituents on the electron injection abilities of unsymmetrical perylene diimide dyes. Dyes Pigm. 2011, 91, 182-191.

10. Ramanan, C.; Semigh, A.L.; Anthony, J.E.; Marks, T.J.; Wasielewski, M.R. Competition between singlet fission and charge separation in solution-processed blend films of 6,13-bis(triisopropylsilylethynyl)-pentacene with sterically-encumbered perylene-3,4:9,10bis(dicarboximide)s. J. Am. Chem. Soc. 2012, 134, 386-397.

11. Shibano, Y.; Umeyama, T.; Matano, Y.; Imahori, H. Electron-donating perylene tetracarboxylic acids for dye-sensitized solar cells. Org. Lett. 2007, 9, 1971-1974.

12. Kozma, E.; Catellani, M. Perylene diimides based materials for organic solar cells. Dyes Pigm. 2013, 98, 160-179.

13. Tian, H.; Liu, P.H.; Zhu, W.; Gao, E.; Wu, D.J.; Cai, S. Synthesis of novel multi-chromophoric soluble perylene derivatives and their photosensitizing properties with wide spectral response for $\mathrm{SnO}_{2}$ nanoporous electrode. J. Mater. Chem. 2000, 10, 2708-2715.

14. Choi, H.; Paek, S.; Song, J.; Kim, C.; Cho, N.; Ko, J. Synthesis of annulated thiophene perylene bisimide analogues: Their applications to bulk heterojunction organic solar cells. Chem. Commun. 2011, 47, 5509-5511.

15. Huang, C.; Barlow, S.; Marder, S.R. Perylene-3,4,9,10-tetracarboxylic acid diimides: Synthesis, physical properties, and use in organic electronics. J. Org. Chem. 2011, 76, 2386-2407. 
16. Wang, H.Y.; Peng, B.; Wei, W. Solar cells based on perylene bisimide derivatives. Prog. Chem. 2008, 20, 1751-1760.

17. Ventura, B.; Langhals, H.; Böck, B.; Flamigni, L. Phosphorescent perylene imides. Chem. Commun. 2012, 48, 4226-4228.

18. Matsui, M.; Wang, M.; Funabiki, K.; Hayakawa, Y.; Kitaguchi, T. Properties of novel perylene-3,4:9,10-tetracarboxidiimide-centred dendrimers and their application as emitters in organic electroluminescence devices. Dyes Pigm. 2007, 74, 169-175.

19. Damaceanu, M.D.; Constantin, C.P.; Bruma, N.; Pinteala, M. Tuning of the color of the emitted light from new polyperyleneimides containing oxadiazole and siloxane moieties. Dyes Pigm. 2013, 99, 228-239.

20. Lucenti, E.; Botta, C.; Cariati, E.; Righetto, S.; Scarpellini, M.; Tordin, E.; Ugo, R. New organic-inorganic hybrid materials based on perylene diimide-polyhedral oligomeric silsesquioxane dyes with reduced quenching of the emission in the solid state. Dyes Pigm. 2013, 96, 748-755.

21. Pan, J.; Zhu, W.; Li, S.; Zeng, W.; Cao, Y.; Tian, H. Dendron-functionalized perylene diimides with carrier-transporting ability for red luminescent materials. Polymer 2005, 46, 7658-7669.

22. Li, X.; Sinks, L.E.; Rybtchinski, B.; Wasielewski, M.R. Ultrafast aggregate-to-aggregate energy transfer within self-assembled light-harvesting columns of zinc phthalocyanine tetrakis(perylenediimide). J. Am. Chem. Soc. 2004, 126, 10810-10811.

23. Rybtchinski, B.; Sinks, L.E.; Wasielewski, M.R. Combining light-harvesting and charge separation in a self-assembled artificial photosynthetic system based on perylenediimide chromophores. J. Am. Chem. Soc. 2004, 126, 12268-12269.

24. Berberich, M.; Krause, A.M.; Orlandi, M.; Scandola, F.; Würthner, F. Toward fluorescent memories with nondestructive readout: Photoswitching of fluorescence by intramolecular electron transfer in a diaryl ethene-perylene bisimide photochromic system. Angew. Chem. Int. Ed. 2008, 47, 6616-6619.

25. Tan, W.; Li, X.; Zhang, J.; Tian, H. A photochromic diarylethene dyad based on perylene diimide. Dyes Pigm. 2011, 89, 260-265.

26. Weiss, E.A.; Ahrens, M.J.; Sinks, L.E.; Gusev, A.V.; Ratner, M.A.; Wasielewski, M.R. Making a molecular wire: Charge and spin transport through para-phenylene oligomers. J. Am. Chem. Soc. 2004, 126, 5577-5584.

27. Wilson, T.M.; Tauber, M.J.; Wasielewski, M.R. Toward an $n$-type molecular wire: Electron hopping within linearly linked perylenediimide oligomers. J. Am. Chem. Soc. 2009, 131, 8952-8957.

28. Choi, J.; Lee, W.; Sakong, C.; Yuk, S.B.; Park, J.S.; Kim, J.P. Facile synthesis and characterization of novel coronene chromophores and their application to LCD color filters. Dyes Pigm. 2012, 94, 34-39.

29. Sakong, C.; Kim, Y.D.; Choi, J.H.; Yoon, C.; Kim, J.P. The synthesis of thermally-stable red dyes for LCD color filters and analysis of their aggregation and spectral properties. Dyes Pigm. 2011, $88,166-173$.

30. Lu, X.; Guo, Z.; Sun, C.; Tian, H.; Zhu, W. Helical assembly induced by hydrogen bonding from chiral carboxylic acids based on perylene bisimides. J. Phys. Chem. B 2011, 115, 10871-10876.

31. Würthner, F. Perylene bisimide dyes as versatile building blocks for functional supramolecular architectures. Chem. Commun. 2004, 14, 1564-1579. 
32. Wasielewski, M.R. Self-assembly strategies for integrating light harvesting and charge separation in artificial photosynthetic systems. Acc. Chem. Res. 2009, 42, 1910-1921.

33. Kaur, B.; Bhattacharya, S.N.; Henry, D.J. Interpreting the near-infrared reflectance of a series of perylene pigments. Dyes Pigm. 2013, 99, 502-511.

34. Georgiev, N.I.; Sakr, A.R.; Bojinov, V.B. Design and synthesis of novel fluorescence sensing perylene diimides based on photoinduced electron transfer. Dyes Pigm. 2011, 91, 332-339.

35. Langhals, H.; Kirner, S. Novel fluorescent dyes by the extension of the core of perylenetetracarboxylic bisimides. Eur. J. Org. Chem. 2000, 2, 365-380.

36. Liang, Y.; Wang, H.; Wang, D.; Liu, H.; Feng, S. The synthesis, morphology and liquid-crystalline property of polysiloxane-modified perylene derivative. Dyes Pigm. 2012, 95, 260-267.

37. Cazacu, M.; Vlad, A.; Airinei, A.; Nicolescu, A.; Stoica, I. New imides based on perylene and siloxane derivatives. Dyes Pigm. 2011, 90, 106-113.

38. Kaur, B.; Quazi, N.; Ivanov, I.; Bhattacharya, S.N. Near-infrared reflective properties of perylene derivatives. Dyes Pigm. 2012, 92, 1108-1113.

39. Boobalan, G.; Imran, P.S.; Nagarajan, S. Synthesis of highly fluorescent and water soluble perylene bisimide. Chin. Chem. Lett. 2012, 23, 149-153.

40. Cui, Y.; Wu, Y.; Liu, Y.; Yang, G.; Liu, L.; Fu, H.; Li, Z.; Wang, S.; Wang, Z.; Chen, Y. PEGylated nanoparticles of diperylene bisimides with high efficiency of ${ }^{1} \mathrm{O}_{2}$ generation. Dyes Pigm. 2013, 97, 129-133.

41. Wang, R.; Shi, Z.; Zhang, C.; Zhang, A.; Chen, J.; Guo, W.; Sun, Z. Facile synthesis and controllable bromination of asymmetrical intermediates of perylene monoanhydride/monoimide diester. Dyes Pigm. 2013, 98, 450-458.

42. Luo, M.H.; Chen, K.Y. Asymmetric perylene bisimide dyes with strong solvatofluorism. Dyes Pigm. 2013, 99, 456-464.

43. Kang, H.; Jiang, W.; Wang, Z. Construction of well-defined butadiynylene-linked perylene bisimide arrays via cross-coupling. Dyes Pigm. 2013, 97, 244-249.

44. Shin, I.S.; Hirsch, T.; Ehrl, B.; Jang, D.H.; Wolfbeis, O.S.; Hong, J.I. Efficient fluorescence "turn-on" sensing of dissolved oxygen by electrochemical switching. Anal. Chem. 2012, 84, 9163-9168.

45. Habuchi, S.; Fujiwara, S.; Yamamoto, T.; Vacha, M.; Tezuka, Y. Single-molecule study on polymer diffusion in a melt state: Effect of chain topology. Anal. Chem. 2013, 85, 7369-7376.

46. Daimon, T.; Nihei, E. Fabrication of a poly(3-octylthiophene-2,5-diyl) electrochemiluminescence device assisted by perylene. Materials 2013, 6, 1704-1717.

47. Sharma, G.D.; Kurchania, R.; Ball, R.J.; Roy, M.S.; Mikroyannidis, J.A. Effect of deoxycholic acid on the performance of liquid electrolyte dye-sensitized solar cells using a perylene monoimide derivative. Int. J. Photoenergy 2012, 2012, doi:10.1155/2012/983081.

48. Tsai, H.Y.; Chang, C.W.; Chen, K.Y. 1,6- and 1,7-Regioisomers of asymmetric and symmetric perylene bisimides: Synthesis, characterization and optical properties. Molecules 2014, 19, 327-341.

49. El-Daly, S.A.; Alamry, K.A.; Asiri, A.M.; Hussein, M.A. Spectral characteristics and fluorescence quenching of $N, N^{\prime}$-bis(4-pyridyl)-3,4:9,10-perylenebis(dicarboximide) (BPPD). J. Lumin. 2012, 132, 2747-2752. 
50. Tsai, H.Y.; Chen, K.Y. Synthesis and optical properties of novel asymmetric perylene bisimides. J. Lumin. 2014, 149, 103-111.

51. Yang, T.; Guan, Q.; Guo, X.; Meng, L.; Du, M.; Jiao, K. Direct and freely switchable detection of target genes engineered by reduced graphene oxide-poly $(m$-aminobenzenesulfonic acid $)$ nanocomposite via synchronous pulse electrosynthesis. Anal. Chem. 2013, 85, 1358-1366.

52. Liao, D.; Chen, J.; Zhou, H.; Wang, Y.; Li, Y.; Yu, C. In situ formation of metal coordination polymer: A strategy for fluorescence turn-on assay of acetylcholinesterase activity and inhibitor screening. Anal. Chem. 2013, 85, 2667-2672.

53. Naveenraj, S.; Raj, M.R.; Anandan, S. Binding interaction between serum albumins and perylene-3,4,9,10-tetracarboxylate-A spectroscopic investigation. Dyes Pigm. 2012, 94, $330-337$.

54. Zhang, L.; Wang, Y.; Yu, J.; Zhang, G.; Cai, X.; Wu, Y.; Wang, L. A colorimetric and fluorescent sensor based on PBIs for palladium detection. Tetrahedron Lett. 2013, 54, 4019-4022.

55. Boobalan, G.; Imran, P.M.; Ramkumar, S.G.; Nagarajan, S. Fabrication of luminescent perylene bisimide nanorods. J. Lumin. 2014, 146, 387-393.

56. Weitz, R.T.; Amsharov, K.; Zschieschang, U.; Villas, E.B.; Goswami, D.K.; Burghard, M.; Dosch, H.; Jansen, M.; Kern, K.; Klauk, H. Organic n-channel transistors based on core-cyanated perylene carboxylic diimide derivatives. J. Am. Chem. Soc. 2008, 130, 4637-4645.

57. Jones, B.A.; Facchetti, A.; Wasielewski, M.R.; Marks, T.J. Tuning orbital energetics in arylene diimide semiconductors. Materials design for ambient stability of $n$-type charge transport. J. Am. Chem. Soc. 2007, 129, 15259-15278.

58. Chen, K.Y.; Chow, T.J. 1,7-Dinitroperylene bisimides: Facile synthesis and characterization as n-type organic semiconductors. Tetrahedron Lett. 2010, 51, 5959-5963.

59. Chen, Z.J.; Wang, L.M.; Zou, G.; Zhang, L.; Zhang, G.J.; Cai, X.F.; Teng, M.S. Colorimetric and ratiometric luorescent chemosensor for fluoride ion based on perylene diimide derivatives. Dyes Pigm. 2012, 94, 410-415.

60. Kong, X.; Gao, J.; Ma, T.; Wang, M.; Zhang, A.; Shi, Z.; Wei, Y. Facile synthesis and replacement reactions of mono-substituteded perylene bisimide dyes. Dyes Pigm. 2012, 95, 450-454.

61. Yuan, Z.; Li, J.; Xiao, Y.; Li, Z.; Qian, X. Core-perfluoroalkylated perylene diimides and naphthalene diimides: Versatile synthesis, solubility, electrochemistry, and optical properties. J. Org. Chem. 2010, 75, 3007-3016.

62. Li, Y.; Tan, L.; Wang, Z.; Qian, H.; Shi, Y.; Hu, W. Air-stable $n$-type semiconductor: Core-perfluoroalkylated perylene bisimides. Org. Lett. 2008, 10, 529-532.

63. Chao, C.C.; Leung, M.K. Photophysical and electrochemical properties of 1,7-diaryl-substituted perylene diimides. J. Org. Chem. 2005, 70, 4323-4331.

64. Miasojedovasa, A.; Kazlauskasa, K.; Armonaitea, G.; Sivamuruganb, V.; Valiyaveettilb, S.; Grazuleviciusc, J.V.; Jursenasa, S. Concentration effects on emission of bay-substituted perylene diimide derivatives in a polymer matrix. Dyes Pigm. 2012, 92, 1285-1291.

65. Goretzki, G.; Davies, E.S.; Argent, S.P.; Warren, J.E.; Blake, A.J.; Champness, N.R. Building multistate redox-active architectures using metal-complex functionalized perylene bis-imides. Inorg. Chem. 2009, 48, 10264-10274. 
66. Dhokale, B.; Gautam, P.; Misra, R. Donor-acceptor perylenediimide-ferrocene conjugates: Synthesis, photophysical, and electrochemical properties. Tetrahedron Lett. 2012, 53, 2352-2354.

67. Dey, S.; Efimov, A.; Lemmetyinen, H. Bay region borylation of perylene bisimides. Eur. J. Org. Chem. 2011, 30, 5955-5958.

68. Handa, N.V.; Mendoza, K.D.; Shirtcliff, L.D. Syntheses and properties of 1,6 and 1,7 perylene diimides and tetracarboxylic dianhydrides. Org. Lett. 2011, 13, 4724-4727.

69. Fin, A.; Petkova, I.; Doval, D.A.; Sakai, N.; Vauthey, E.; Matile, S. Naphthalene- and perylenediimides with hydroquinones, catechols, boronic esters and imines in the core. Org. Biomol. Chem. 2011, 9, 8246-8252.

70. Perrin, L.; Hudhomme, P. Synthesis, electrochemical and optical absorption properties of new perylene-3,4:9,10-bis(dicarboximide) and perylene-3,4:9,10-bis(benzimidazole) derivatives. Eur. J. Org. Chem. 2011, 28, 5427-5440.

71. Dinçalp, H.; Kızılok, Ş.; İçli, S. Fluorescent macromolecular perylene diimides containing pyrene or indole units in bay positions. Dyes Pigm. 2010, 86, 32-41.

72. Zhao, C.; Zhang, Y.; Li, R.; Li, X.; Jiang, J. Di(alkoxy)- and di(alkylthio)-substituted perylene-3,4;9,10-tetracarboxy diimides with tunable electrochemical and photophysical properties. J. Org. Chem. 2007, 72, 2402-2410.

73. Ren, H.; Li, J.; Zhang, T.; Wang, R.; Gao, Z.; Liu, D. Synthesis and properties of novel perylenebisimide-cored dendrimers. Dyes Pigm. 2011, 91, 298-303.

74. Zhang, X.; Pang, S.; Zhang, Z.; Ding, X.; Zhang, S.; He, S.; Zhan, C. Facile synthesis of 1-bromo7-alkoxyl perylene diimide dyes: Toward unsymmetrical functionalizations at the 1,7-positions. Tetrahedron Lett. 2012, 53, 1094-1097.

75. Feng, J.; Wang, D.; Wang, S.; Zhang, L.; Li, X. Synthesis and properties of novel perylenetetracarboxylic diimide derivatives fused with BODIPY units. Dyes Pigm. 2011, 89, 23-28.

76. Chen, K.Y.; Fang, T.C.; Chang, M.J. Synthesis, photophysical and electrochemical properties of 1-aminoperylene bisimides. Dyes Pigm. 2011, 92, 517-523.

77. Tsai, H.Y.; Chen, K.Y. 1,7-Diaminoperylene bisimides: Synthesis, optical and electrochemical properties. Dyes Pigm. 2013, 96, 319-327.

78. Ahrens, M.J.; Tauber, M.J.; Wasielewski, M.R. Bis(n-octylamino)perylene-3,4:9,10bis(dicarboximide)s and their radical cations: Synthesis, electrochemistry, and ENDOR spectroscopy. J. Org. Chem. 2006, 71, 2107-2114.

79. Alvino, A.; Franceschin, M.; Cefaro, C.; Borioni, S.; Ortaggi, G.; Bianco, A. Synthesis and spectroscopic properties of highly water-soluble perylene derivatives. Tetrahedron 2007, 63, 7858-7865.

80. Wang, H.; Kaiser, T.E.; Uemura, S.; Würthner, F. Perylene bisimide J-aggregates with absorption maxima in the NIR. Chem. Commun. 2008, 10, 1181-1183.

81. Dubey, R.K.; Efimov, A.; Lemmetyinen, H. 1,7- and 1,6-regioisomers of diphenoxy and dipyrrolidinyl substituted perylene diimides: Synthesis, separation, characterization, and comparison of electrochemical and optical properties. Chem. Mater. 2011, 23, 778-788.

82. Zhao, Y.; Wasielewski, M.R. 3,4:9,10-Perylenebis(dicarboximide) chromophores that function as both electron donors and acceptors. Tetrahedron Lett. 1999, 40, 7047-7050. 
83. Ma, Y.S.; Wang, C.H.; Zhao, Y.J.; Yu, Y.; Han, C.X.; Qiu, X.J.; Shi, Z. Perylene diimide dyes aggregates: Optical properties and packing behavior in solution and solid state. Supramol. Chem. 2007, 19, 141-149.

84. Fan, L.; Xu, Y.; Tian, H. 1,6-Disubstituted perylene bisimides: Concise synthesis and characterization as near-infrared fluorescent dyes. Tetrahedron Lett. 2005, 46, 4443-4447.

85. Rohr, U.; Kohl, C.; Müllen, K.; van de Craats, A.; Warman, J. Liquid crystalline coronene derivatives. J. Mater. Chem. 2001, 11, 1789-1799.

86. Rajasingh, P.; Cohen, R.; Shirman, E.; Shimon, L.J.W.; Rybtchinski, B. Selective bromination of perylene diimides under mild conditions. J. Org. Chem. 2007, 72, 5973-5979.

87. Lakowicz, J.R. Principles of Fluorescence Spectroscopy, 2nd ed.; Plenum: New York, NY, USA, 1999.

88. Luo, M.H.; Tsai, H.Y.; Lin, H.Y.; Fang, S.K.; Chen, K.Y. Extensive spectral tuning of the proton transfer emission from green to red via a rational derivatization of salicylideneaniline. Chin. Chem. Lett. 2012, 23, 1279-1282.

89. Fang, T.C.; Tsai, H.Y.; Luo, M.H.; Chang, C.W.; Chen, K.Y. Excited-state charge coupled proton transfer reaction via the dipolar functionality of salicylideneaniline. Chin. Chem. Lett. 2013, 24, $145-148$.

(C) 2014 by the authors; licensee MDPI, Basel, Switzerland. This article is an open access article distributed under the terms and conditions of the Creative Commons Attribution license (http://creativecommons.org/licenses/by/3.0/). 